\title{
Editorial
}

\section{The current academic debate calls for critical discussion}

Place Branding and Public Diplomacy (2016) 12, 1-4. doi:10.1057/pb.2016.2

In May 2015 the 3rd Institute of Place Management Conference was held in Poznań (Poland). For the first time not only the Journal of Place Management and Development, but also the journal of Place Branding and Public Diplomacy publishes a special issue with selected papers that were presented in Poznan, including the paper that received the Palgrave Macmillan best paper award. The idea is to present a wide variety of papers from different academic disciplines. While conference papers sometimes may need more time to advance the argument, they represent a great overview of the current development of our field and could serve as an inspiration for other researchers to discuss and enhance different ideas. Thus, for this special issue we selected seven papers that hopefully will inspire the readership of the journal - as they did the conference participants.

In the first paper (Urban brandscape as value ecosystem: the "cultural destination strategy' of fashion brands), the 'Conference Best Paper Award' winners Nicola Bellini and Cecilia Pasquinelli describe how company brands influence the perception of places. By analyzing the historical connection between Florance (Italy) and iconic brands from the fashion industry they go beyond the place-of-origin effect (which focuses on the effect of the place on the product) but look at the reciprocal relationship of this effect (that places are also influenced by the products they export). In doing so, the authors present a case where fashion firms become part of the city tourism scene.

The second paper by Fabiana Mariutti and Ralph Tench, 'How does Brazil measure up? Comparing rankings through the lenses of nation brand indexes', discuss the diverse positions of Brazil in different nation rankings. In practice, place brand rankings are popular as ever and place managers use them in their desperate search for success measures. Looking at four different indexes in more depth, the authors explain how the methodology varies and why perceptions differ in the case of Brazil. In doing so, the authors question the common use of place rankings as valid success measurement, but at the same time, also show that these rankings have their use as complementary measurement tools.

Hong Fan and Anastasia Poshinova discuss - in the third article entitled 'Beijing capitalness and related challenges - Russian media perspective' - the different images of China in the Russian media. In particular they study the extent to which the Chinese capital Beijing represents the image of China in the media, showing that a capital city may have problems in communicating a distinctive image, other than the national image, as it always represents some kind of 'capitalness' and works as a stereotype for the nation as well.

In the fourth paper (Restriction on the use of the Aaker model in the measurement of city brand personality - the sender's perspective), Ewa Glińska and Oleg 
Gorbaniuk, show a different perspective on the brand personality scales developed by Jennifer L. Aaker. In the product branding field the personality scale is a widely accepted measurement tool and also in place branding attempts have been made to use this method. However, looking at how the senders of place brand communication (city promotion managers) intend to communicate about the place, the findings of this article reveal that the brand personality scale may not be as fruitful a method for place branding as one might think, as it disregards important city personality dimensions and incorporates others that may not be highly relevant for places.

The fifth paper, by Olga Kolotouchkina Shvedova and Gildo Seisdedos named 'The urban cultural appeal matrix: Identifying key elements of the cultural city brand profile using the example of Madrid' focuses on an 'evergreen' of place branding: The use of cultural aspects as a part of the city brand. In their analysis of the Madrid case the authors investigate the cultural offers of Madrid, as perceived by Madrid visitors, and define hard and soft factors shaping the perception of an urban place brand in terms of its cultural entertainment offer. In doing so, they address important areas of our current place brand discussion: The difference between the needs and perception of tourists versus other target audiences of a city, as well as the strong trend of places to differentiate through culture. With their cultural appeal matrix, the authors offer a tool for policymakers to think more strategically about the role of culture in place branding.

The sixth paper, by Ole Have Jørgensen, offers a different geographical and disciplinary perspective. 'Place and city branding in the Danish municipalities with focus on political involvement and leadership' seeks to give a status-quo of the current place branding development among Danish municipalities. In a nation-wide study the author reveals the reasons for place branding of Danish municipalities and links these to the underlying place development strategy. He also studies the issue of project ownership, financial funding and the subject of political leadership. In doing so, he discusses special characteristics of Danish place branding, but also delivers fruitful insights in the general reasoning of place branding.

Finally, the seventh paper represents an example for our case study section: Joao Freire presents in his article 'Managing destination brand architecture - The case of Cascais municipality', an example of a region that needs more complex place brand architecture. Focusing on destination branding and the external perception of the region, the case shows that regional cooperation is an effective place branding strategy. However, this calls for a clear umbrella and sub-brand structure to use the potential of cooperative regional branding in a more efficient way.

This selection of papers does not only cover a wide range of different topics, place levels, geographical and interdisciplinary perspectives, but also combines findings from researchers and practitioners' alike - representing the spirit of the place branding conference in Poznań. At the same time, such a meeting of international researchers and practitioners is also the right moment to critically question the field of study. Even though our first meta-analyses of the place branding literature (Gertner, 2011; Lucarelli and Berg, 2011; Lucarelli and Brorström, 2013) highlight the exponential growth in contributions, they also criticize the lack of theoretical and conceptual background of our articles. This lack of scientific rigor is surprising, as place researchers have the opportunity to borrow numerous concepts and theories from many different disciplines.

Unfortunately, there has been limited work on translating current knowledge from other disciplines for use in our field and consequently, we are sometimes stuck at the same level of discussion.

As a discipline we have to admit that our field underperforms in the areas of academic rigor and theory development. Other disciplines improved their empirical and theoretical skills and raised the bar for publications. For example, while single case studies remain common in place branding, they would be considered substandard by high-ranking marketing journals. Such journals look for empirical results underpinned by a solid theoretical foundation and for more generalizability than can be derived from 
practitioner problems in any one particular place. In place branding in general, and in the Place Branding and Public Diplomacy journal in particular, we are proud of our close link between the practical and academic spheres. However, we often forget about the need to improve general knowledge and further develop place branding as an academic field. Dozens of single case studies with only very case specific results and poor theoretical conceptualization are not providing enough contribution in this regards. Linking cases to theoretical knowledge and deriving general learnings by comparing and contrasting multiple cases is key.

In fairness, the academic discussion has improved in recent years. In early place branding publications scholars and others focused extensively on phraseology, definitions and awareness raising. Today, the common knowledge about the subject is growing. This growth has led place branding to become this highly interdisciplinary topic that it is today. While valuable, this development presents a particular challenge, as researchers and practitioners from different disciplines do not necessarily speak the same language. Unsurprisingly, then, many contemporary articles do not use up-to-date definitions of place branding (for example, still misunderstanding it as a limited approach to place promotion) and there is still insufficient insight and agreement with regards to the distinctiveness, overlaps and linkages between: public diplomacy and place branding; place marketing and place branding; destination branding and place branding; place management and place branding or place making and place branding. We, as academic community should enhance our understanding and defend our field more thoroughly in this regards.

Some have asked whether place branding is worth the effort (Medway et al, 2015). If, in practice, nobody really owns the brand and policymakers lack the power to really influence it, then why should anyone care? If successes are hard to measure, but policymakers demand hard numbers to prove the effective investment of public and private resources, then why should we try? If results are hard to publish because of the field's interdisciplinary background and low academic reputation, then why should we suffer? Because it is worth it. The field is one of the few final frontiers, where we have the chance to combine theories from all our disciplines. It is an area where researchers and practitioners can still help one another in pursuit of a common goal making places better. It is not a simple or easy undertaking, but we are convinced that place branding can be applied to help places become more meaningful and satisfying to the people who use them. Thus, place branding is not a waste of time, but a great field of research with practical utility - as long as we are willing to push us beyond our comfort zones. Science should be a domain for discussion and development, but this is only possible if we work hard to maintain an atmosphere of debate. While there are sometimes unavoidable politics involved in academic publishing (such as referencing everybody to please potential reviewers or ignoring poor academic work to not displease anyone), it is important that these do not impede the discussion, and sometimes conflict, that is necessary for scientific advancement. To quote Oliver Kahn, former keeper of the German national soccer team: 'Eierwir brauchen Eier! [We need guts!]' - no gender bias intended. Many journals offer a publication type called 'viewpoints', 'commentaries and rejoinders' or 'opinion pieces' as one way to have quick access to publication and hence debate (here in Place Branding and Public Diplomacy we call them 'think pieces'). One idea or opinion about a published paper could be discussed within such a section. In doing so, we could criticize problems in scientific rigor, broaden discussion, add new angles and create better knowledge - replicating the spirit of the general big debates in academia from the $60 \mathrm{~s}$ and 70 s to our field.

Thus, we invite your response to this special issue: The chosen conference papers are 'brand new' and some may have needed more time for their development. However, they are a good representation of our present-day debate and touch the areas we are currently discussing. So please use and discuss these articles, definitions, findings or propositions. Tear them apart, change them or enhance them with content from your 
discipline. Only by engaging in critical and constructive debate can we improve our field of research.

\section{REFERENCES}

Gertner, D. (2011) Unfolding and configuring two decades of research and publications on place marketing and place branding. Place Branding and Public Diplomacy 7(2): 91-106.

Lucarelli, A. and Berg, P.O. (2011) City branding: A state-ofthe-art review of the research domain. Journal of Place Management and Development 4(1): 9-27.

Lucarelli, A. and Brorström, S. (2013) Problematizing place branding research: A meta-theoretical analysis of the literature. The Marketing Review 13(1): 65-81.
Medway, D., Swanson, K., Delpy Neirotti, L., Pasquinelli, C. and Zenker, S. (2015) Place branding: Are we wasting our time? Report of an AMA special session. Journal of Place Management and Development 8(1): 63-68.

Sebastian Zenker Assistant Professor, Copenhagen Business School, Copenhagen, Denmark E-mail: sze.marktg@cbs.dk

Robert Govers Independent advisor, scholar and author on Place Branding, Antwerp, Belgium

E-mail: rgovers@rgovers.com 